\title{
Analisis Peran Perbankan Terhadap Pertumbuhan Ekonomi di Indonesia: Bank Syariah Versus Bank Konvensional
}

\author{
Iwan Setiawan * \\ * Politeknik Negeri Bandung \\ Jurusan Akuntansi \\ Program Studi Magister Terapan Keuangan dan Perbankan Syariah \\ Bandung, Jawa Barat, Indonesia \\ E-mail: iwan.setiawan@polban.ac.id
}

\begin{abstract}
Abstrak
Penelitian ini dilakukan untuk mengetahui apakah kredit dan pembiayaan bank mendorong kegiatan dan pertumbuhan ekonomi. Penelitian dilakukan dengan menggunakan metode eksplanatori, menerapkan model persamaan regresi berganda dengan metode analisis data regresi ordinary least square (OLS), menggunakan data perkonomian Indonesia untuk periode 1992-2018. Hasil penelitian ini mengungkapkan bahwa kredit bank konvensional dan pembiayaan bank syariah secara signifikan mempengaruhi pertumbuhan ekonomi. Peningkatan kredit dan pembiayaan memiliki efek positif pada pertumbuhan ekonomi. Setiap peningkatan kredit bank konvensional menghasilkan peningkatan pertumbuhan ekonomi. Efek perubahan tidak terlalu besar, tidak elastis, tetapi efeknya signifikan. Setiap peningkatan nilai kredit dan pembiayaan di industri perbankan domestik memiliki potensi untuk menyebabkan pertumbuhan ekonomi. Efek kredit bank konvensional terhadap pertumbuhan ekonomi lebih besar daripada efek pembiayaan bank syariah terhadap pertumbuhan ekonomi. Kredit bank konvensional relatif lebih elastis mendorong pertumbuhan ekonomi dibandingkan dengan bank syariah.
\end{abstract}

Kata Kunci : Pembiayaan, kredit, kebijakan moneter, inflasi, pertumbuhan ekonomi

\begin{abstract}
This research was conducted to find out whether bank credit and financing encourage economic activity and growth. The study was conducted using explanatory methods, applying the multiple regression equation model with ordinary least square (OLS) regression data analysis methods, using Indonesian economic data for the period 1992-2018. The results of this study reveal that conventional bank credit and Islamic bank financing significantly influence the economic growth. Increased credit and financing have a positive effect on economic growth. Every increase in conventional bank credit results in an increase in economic growth. The effect of change is not too large, is inelastic, but the effect is significant. Every increase in the value of credit and financing in the domestic banking industry has the potential to cause economic growth. The effect of conventional bank credit on economic growth is greater than the effect of Islamic bank financing on economic growth. Conventional bank credit is relatively more elastic encouraging economic growth compared to Islamic banks.
\end{abstract}

Keywords: Financing, credit, monetary policy, inflation, economic growth

\section{Pendahuluan}

Kehadiran bank syariah hadir melengkapi keberadaan bank konvensional dalam sistem perbankan ganda perekonomian Indonesia. Perbankan syariah mengalami perkembangan yang pesat, terutama pada masa sebelum dan pasca krisis ekonomi di tahun 1998. Dalam rentang tahun 1992-2016 perkembangan pembiayaan bank syariah tumbuh sebesar $61.98 \%$ per tahun. Perkembangan pembiayaan bank syariah melampaui perkembangan kredit dari bank konvensional. Dalam rentang waktu 1992-2016 perkembangan kredit bank konvensional tumbuh sebesar $18.22 \%$ per tahun.

Menurut Abdullah (2003) bank syariah memiliki keunggulan yang tidak dapat tersaingi oleh bank konvensional. Standar moral Islam dan azas keadilan dalam bank syariah akan mendorong terciptanya sinergi yang sangat bermanfaat bagi bank, nasabah dan masyarakat. Kajian lintas negara dari Beck, et all.

52 | Jurnal Akuntansi, Ekonomi dan Manajemen Bisnis | Vol. 8 No.1, July 2020, 52-60 | E-ISSN: 2548-9836 
(2013) menunjukan bahwa bank syariah memiliki rasio intermediasi lebih tinggi, kualitas aset yang lebih tinggi dan dikapitalisasi lebih baik dari bank konvensional. Selama krisis, kapitalisasi dan kualitas asset bank syariah juga tampil lebih baik dari bank konvensional. Salah satu kelemahan yang melekat pada bank syariah adalah bank syariah kurang efisien dibandingkan dengan bank konvensional.

Kajian dari Zirek, D., et all (2016) mengungkapkan bahwa ada hubungan yang signifikan dan sejalan antara lembaga keuangan syariah dan pertumbuhan ekonomi. Peningkatan dana pihak ketiga, aktiva dan pembiayaan bank syariah mendorong terjadinya pertumbuhan ekonomi. Dalam jangka penjang, perkembangan ekonomi juga merespon searah terhadap penerapan instrumen kebijakan moneter syariah. Kajian Hasan dan Dridi (2010) mengungkapkan bahwa sumbangan perbankan syariah terhadap stabilisasi kondisi pasar keuangan dan perekonomian lebih besar daripada sumbangan yang diberikan oleh perbankan konvensional.

Kondisi yang unik dari bank syariah adalah larangan riba dalam transaksi perbankan yang dijalankannya. Pengharaman bunga dalam alokasi pembiayaan, perbaikan organisasi fungsi intermediasi dan sistem 'profit-loss sharing' dari bank syariah dapat mengurangi aktivitas tidak produktif dan tindakan spekulatif dalam perekonomian. Kondisi ini sangat berbeda dengan kondisi perekonomian yang prinsip operasionalnya menggunakan sistem bunga. Menurut Chapra (2007) sistem ribawi (bunga) menimbulkan dampak adanya inefisiensi dalam distribusi sumber dana serta mendorong terjadinya ketimpangan pembagian pendapatan/ kekayaan dalam masyarakat.

Perekonomian yang memberlakukan sistem perbankan ganda, pelaksana kebijakan moneter bertanggung jawab memelihara kondisi stabilitas moneter dan sistem keuangan. Otoritas moneter harus mampu menyelaraskan sistem perbankan konvensional dan syariah sehingga dapat tercapai keuntungan optimal yang dapat memperbaiki kesejahteraan masyarakat. Substansi dan karakteristik dari masing-masing sistem harus tetap terjaga dan tidak meleburkan salah satu sistem ke sistem yang lain. Menurut Ascarya, et all (2008) harmonisasi berkesinambungan memastikan stabilitas sistem keuangan, mempercepat aktivitas ekonomi dan meningkatkan kesejahteraan secara merata.

Menurut kajian dari Elhiraika (2004) pelaksanaan kebijakan moneter dalam jangka pendek menghasilkan dampak yang sama bagi bank perbankan konvensional dan perbankan syariah. Perbedaan dampak kebijakan moneter bagi perbankan konvensional dan perbankan syariah akan diperoleh dalam jangka panjang. Dalam jangka panjang keunggulan sistem perbankan syariah tergantung dari lingkungan makro ekonomi yang dihadirkan oleh pemerintah. Jika pemerintah mampu menciptakan lingkungan yang kondusif, adanya reformasi dalam institusi dan pembangunan, maka sistem perbankan syariah akan memberikan pengaruh lebih besar terhadap jumlah simpanan dan investasi yang dilakukan masyarakat. Kondisi ini merupakan syarat terjadinya stimulus yang akan mempercepat terjadiya pertumbuhan ekonomi.

Kajian dari Lehnert \& Kchouri (2019) mengungkapkan bahwa meskipun ukuran bank syariah relatif masih kecil dibandingkan dengan total sektor keuangan yang ada, tetapi perbankan syariah memberikan kontribusi positif terhadap pertumbuhan ekonomi. Perkembangan jumlah pembiayaan di bank syariah pada sektor ekonomi teralokasi tidak merata. Pada tahun 2016 sektor kegiatan usaha yang memdapat alokasi pembiayaan paling besar adalah sektor bidang keuangan memperoleh 24,7\%, sektor industri memperoleh $3,16 \%$ dan pertanian memperoleh $1,87 \%$ dari seluruh pembiayaan bank syariah terhadap sektor usaha. Berkembangnya jumlah pembiayaan diharapkan mampu mendorong kegiatan pada sektor tersebut dan meningkatkan sumbangan terhadap pembentukan GDP.

Dalam pembentukan GDP di Indonesia tahun 2016, kontribusi sektor pertanian sebesar 12,93\%, kontribusi sektor industri sebesar 25,38\%, dan kontribusi sektor keuangan sebesar 9,62\%. Dalam penyerapan lapangan kerja, di Indonesia pada tahun 2012 sektor petanian menyerap sebesar 35,09\%, sektor industri menyerap sebesar $13,87 \%$ dan sektor keuangan hanya menyerap sebesar $2,40 \%$ tenaga kerja. Terjadi trend penurunan porsi pembiayaan bank syariah untuk sektor pertanian dan industri dalam beberapa tahun terakhir. Kondisi ini menunjukan bahwa pola pembiayaan bank syariah kurang memberikan penguatan struktur ekonomi yang memberikan kontribusi terhadap pembentukan GDP.

Berdasarkan besarnya potensi dimiliki tapi masih rendahya porsi pembiayaan bank syariah dibandingkan kredit bank konvensional, akan diteliti bagaimana peran dan pengaruhnya terhadap perkembangan ekonomi di Indonesia. Penelitian ini akan mengkaji peran bank syariah dan bank konvensional dalam dual banking system terhadap pertumbuhan ekonomi di Indonesia. Rumusan pertanyaan yang diajukan dalam penelitian ini adalah sebagai berikut ; 1) Apakah bank syariah, melalui peran pembiayaan, memberikan kontribusi terhadap pertumbuhan ekonomi 2) Apakah bank konvensional, melalui peran kredit, memberikan kontribusi terhadap pertumbuhan ekonomi 3)Apakah bank syariah berperan lebih besar terhadap pertumbuhan ekonomi dibandingkan dengan bank konvensional 


\section{Tinjauan Pustaka}

Perbankan melalui aktivitas kredit memiliki peran mendorong pertumbuhan ekonomi. Kajian dari Kaleem (2000) mengungkapkan bahwa pertumbuhan ekonomi di negara berkembang termasuk Indonesia tidak bisa dipisahkan dari peran kredit perbankan. Untuk negara yang memiliki pasar modal yang belum begitu berkembang, kredit bank efektif mempengaruhi perekonomian. Menurut Mendoza \& Terrones (2008), pada umumnya krisis ekonomi seperti yang terjadi di Indonesia, terkait dengan peningkatan kredit yang didahului oleh arus masuk modal yang besar tetapi tidak dengan disertai dengan reformasi sistem keuangan. Dalam perekonomian yang menerapkan sistem perbankan ganda, kredit bank konvensional (CRD) dan pembiayaan bank syariah (FIN) turut berperan terhadap pertumbuhan ekonomi. Kajian dari Rusyidiana (2009) dan Ascarya (2010) mengungkapkan bahwa pembiayaan produktif berpengaruh positif terhadap output sektor riil memungkinkan terjadi pertumbuhan seimbang antara sektor moneter dan sektor riil.

Kajian dari Lebdaoui \& Wild (2016) mengungkapkan bahwa keberadaan perbankan Islam terbukti memberikan sumbangan terhadap perkembangan perekonomian untuk periode waktu jangka panjang. Masyarakat muslim juga memberikan peran positif dan signifikan terhadap peningkatan pangsa pasar perbankan Islam di dalam sektor keuangan. Pertumbuhan ekonomi dari sisi penawaran digambarkan oleh distribusi PDB menurut sektor ekonomi atau lapangan usaha. Upaya yang dilakukan pemerintah untuk mendorong pertumbuhan ekonomi dilakukan melalui kebijakan moneter yang terimplementasi melalui kredit perbankan. Kajian dari Alam \& Waheed (2006) serta Saibu M. O \& Nwosa I (2011) mengungkap bahwa masing-masing sektor ekonomi memiliki sensitifitas yang berbeda dalam merespon kebijakan moneter berbeda. Sektor manufaktur tidak sensitif sedangkan sektor pertanian responsif terhadap perubahan suku bunga kebijakan moneter. Kebijakan moneter akan efektif jika perbedaan respon dari masing-masing sektor ekonomi dipertimbangkan dalam desain kebijakan moneter.

Pelaksanaan kredit pada bank konvensional dan pembiayaan pada bank syariah dapat mendorong permintaan aggregat dan menambah penciptaan lapangan kerja. Hasil penelitian Hadiati (2010), Ozcelebi (2011), Cambazoğlu dan Karaalp (2012) yang mengungkap adanya hubungan antara penyaluran kredit dengan pertumbuhan ekonomi. Hubungan searah antara kredit bank konvensional dengan pertumbuhan ekonomi dijelaskan dengan mengkaji alokasi kredit berdasarkan tujuan penggunaan dan sektor ekonomi. Sektor manufaktur memperoleh kredit terbesar dari bank konvensional. Kredit disalurkan untuk tujuan produktif dalam bentuk kredit modal kerja dan investasi. Hasil dari proses alokasi kredit menunjukan bahwa sektor manufaktur (industri pengolahan) memberikan sumbangan terbesar pada pembentukan GDP di Indonesia.

Kajian dari Hakim Bm \& Uddin (2016), mengungkapkan bank Islam di Malaysia memainkan peran penting terhadap pertumbuhan ekonomi. Bersama dengan lembaga keuangan Islam lainnya, bank Islam mendorong permintaan efektif, memfasilitasi akumulasi modal dan pertumbuhan ekonomi. Disarankan peningkatan porsi portfolio pembiayaan bank syariah di Malaysia. Hasil kajian dari Hachicha \& Ben Amar, A. (2015) mengungkapkan bahwa dalam jangka panjang, pertumbuhan ekonomi di Malaysia tidak sensitif terhadap pembiayaan dari bank Islam. Efek dari berbagai indikator keuangan Islam terhadap pertumbuhan ekonomi dalam jangka panjang kurang begitu penting dibandingkan dengan efek jangka pendek. Struktur pembiayaan bank syariah di Malaysia kurang menganggap penting instrumen sistem bagi hasil. Bank-bank Islam di Malaysia lebih banyak terlibat daam kegiatan non partisiatif yang lebih memberikan dampak dalam jangka pendek.

Perkembangan Bank Syariah belum optimal, baik dari sisi dana pihak ketiga maupun dari sisi alokasi pembiayaan. Kajian dari Rusydiana (2016) mengungkapkan bahwa masalah yang dihadapi oleh bank syariah di Indonesia adalah permodalan yang belum mamadai, lemahnya kuallitas SDM, terbatasnya dukungan dari pemerintah dan rendahnya kepeprcayaan dan minat masyarakat terhadap bank syariah. Maka strategi kebijakan yang diusulkan sebagai solusi permasalahan industri perbankan syariah di Indonesia adalah 1) menambah modal, skala usaha dan efisiensi. 2) memperbaiki kuantitas \& kualitas SDM beserta sistim informasi dan teknologi; 3) memperbaiki struktur dana bank dan keselarasann aturan dan kontrol dari otoritas moneter dan perbankan.

Kajian terkini dari Jawad \& Christian, (2019) mengungkapkan upaya untuk memperbesar aktivitas bank syariah (IBD) terbukti memberikan sumbangan terhadap meningkatnya perkembangan ekonomi. Kajian yang dilakukan pada 24 negara untuk periode 2004-2014 menguji hipotesis konvensional tentang penawaran atau permintaan penawaran antara IBD dan pertumbuhan. Hasil kajian menunjukkan bahwa IBD mempengaruhi pertumbuhan secara positif dan ditunjukkan adanya hubungan jangka panjang antara IBD dan pertumbuhan. Perkembangan bank syariah mengikuti trend perkembangan dunia keuangan dan teknologi. Barata (2019), mengungkapkan bahwa E-commerce syariah dan Fintech syariah harus memberikan pengaruh besar pada pertumbuhan ekonomi dan menyerap lebih banyak tenaga kerja. Pertumbuhan ekonomi, peningkatan pendapatan, dan penciptaan lapangan kerja akan berpotensi mengurangi kemiskinan dan ketidaksetaraan. Dalam jangka panjang perkembangan bank syariah dengan memanfaatkan E-commerce dan Fintech berimplikasi semakin kuatnya pertumbuhan ekonomi nasional yang 
berkelanjutan.

Hasil kajian Fikri (2019) mengungkapkan bahwa dalam jangka panjang jalur kredit dan pembiayaan cukup relevan dimanfaatkan dalam mekanisme transmisi moneter pasca pengembangan sektor keuangan dan perubahan kebijakan moneter. Kredit dan pembiayaan memberikan dampak pada pertumbuhan ekonomi dan tidak berpengaruh pada inflasi. Jalur kredit dan pembiayaan dianggap semakin lemah dalam mekanisme transmisi moneter. Penelitian Shah \& Abdul (2019) untuk kasus di Pakistan dan Malaysia Kami mengungkapkan keberadaan jalur kredit di kedua negara dan dampak kebijakan moneter yang berbeda di kedua negara. Supaya kebijakan dan instrumen yang digunakan efektif, perlu dipertimbangkan sifat bank syariah pada masing-masing negara yang menerapkan sistem perbankan ganda. Hasil kajian dari Ahmad \&Ismail (2019) mengungkapkan bahwa perkembangan ekonomi signifikan sebagai indikator kebijakan moneter di masa depan. Diusulkan indikator pertumbuhan ekonomi diterapkan sebagai instrumen kebijakan moneter dalam sistem perbankan ganda oleh bank sentral.

Kredit/pembiayaan merupakan salah satu instrumen penting dalam kebijakan moneter di Indonesia. Penurunan fungsi intermediasi bank yang disebabkan oleh dominasi faktor informasi asimetris berakibat pada menurunnya efektivitas kebijakan moneter (Alamsyah dll, 2005). Peningkatan rasio kredit terhadap nilai aktivitas ekonomi (GDP) secara signifikan mendorong efektivitas pelaksanaan kebijakan moneter, menurunkan laju dan deviasi pencapaian target inflasi (Prastowo \& Depari, 2008). Alokasi pembiayaan bank syariah meningkat sejalan perkembangan aktivitas ekonomi dan tingkat harga (inflasi) yang relatif stabil. Indonesia adalah negara dengan tingkat pertumbuhan ekonomi yang lambat dengan distribusi tidak merata. Pertumbuhan lapangan kerja lambat dan menurun pada sektor formal. Kondisi kemiskinan berfluktuasi dengan kecendrungan menurun.

Kajian tentang kebijakan moneter serta hubungannya dengan inflasi dan pertumbuhan ekonomi telah banyak dilakukan. Banjarnahor (2008) menunjukan hubungan tidak langsung antara suku bunga SBI dengan perkembangan harga dan output. Selain masalah moneter, inflasi juga berhubungan dengan masalah hambatan stuktural yang penanganannya harus melibatkan sektor riil. Pengaruh langsung pentingnya suku SBI terhadap inflasi dan pertumbuhan ekonomi dilakukan oleh Julaihah \& Insukindro (2004). Kebijakan moneter melalui intrumen suku bunga SBI signifikan mempengaruhi infasi dan pertumbuhan output.

Instrumen kebijakan yang diterbitkan oleh otoritas moneter (Bank Indonesia) diharapkan memberi kontribusi terhadap perkembangan perekonomian Indonesia. Hasil kajian dari Sutikno
(2007 menunjukan pengaturan suku bunga kebijakan (SBI) memberikan kontribusi pada perkembanngan harga (inflasi). Kondisi ini menunjukan efektivitas dan kredibilitas kebijakan dari pemilik otoritas moneter. Selain tingkat suku bunga, nilai tukar (kurs) yang terkait dengan aktivitas perdagangan luar negeri juga memberikan kontribusi yang berar terhadap perkembangan harga (inflasi) di dalam negeri.

Kebedaraan bank dalam aktivitas ekonomi tidak bisa lepas dari peran bank sentral sebagai pemegang otoritas moneter. Bank sentral melalui instrumen kebijakan moneter berupaya mengendalikan kondisi perekonomian supaya bisa mencapai kondisi ideal, terjadi pertumbuhan ekonomi disertai dengan stabilitas harga. Hasil kajian dari Ascarya (2010) dan Sukmana (2011) yang mengungkap bahwa peningkatan intrumen kebijakan cenderung diikuti oleh penurunan tingkat harga dan secara umum kegiatan ekonomi merespon negatif kenaikan instrumen kebijakan (Islam \& konvensional). Kajian dari Craig \& Rochteau (2006) mengungkapkan inflasi memiliki dampak negatif terhadap keseimbangan perekonomian dan inflasi mempengaruhi keputusan pelaku bisnis untuk berpatisipasi di pasar dan karena itu mempengaruhi jumlah perdagangan. Pengendalian inflasi merupakan proses penting dalam pembangunan ekonomi untuk mencapai kesejahteraan masyarakat suatu negara. Hasil kajian dari Palley (2007) menunjukan fakta yang kontradiktif dengan penelitian sebelumnya. Berdasarkan hasil penelitian, pelaksanaan kebijakan moneter memberikan dampak negatif terhadap kondisi penciptaan lapangan kerja dan perkembangan ekonomi. Kondisi ini terjadi jika kebijakan moneter yang dilakukan terlalu fokus pada pencapaian tingkat inflasi yang rendah.

Berdasarkan uraian di atas dan tujuan penelitian peran perbankan syariah terhadap pertumbuhan ekonomi di Indonesia, kerangka berfikir penelitian ini disajikan dalam gambar 1 berikut ini.

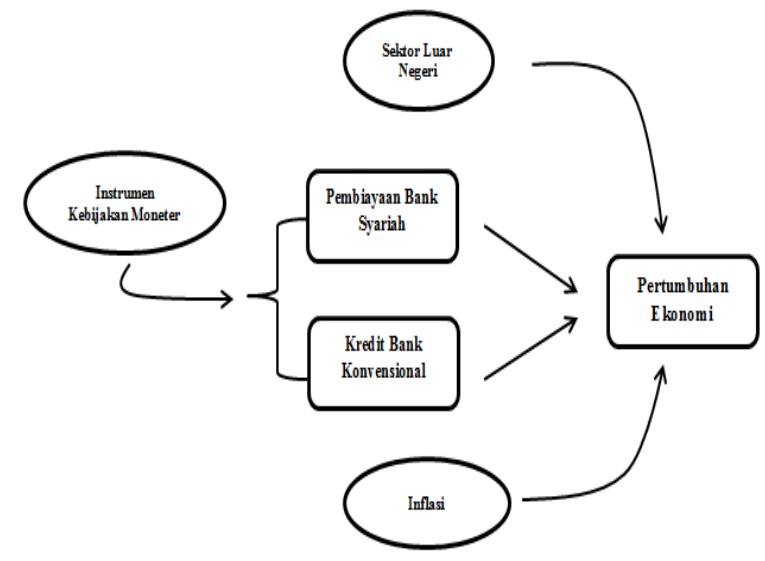

Gambar 1 ; Kerangka Pemikiran Penelitian 


\section{Metode Penelitian}

Penelitian yang dilakukan menggunakan model persamaan regresi berganda satu tahap (ordinary least square). Dalam model persamaan terlihat peran bank syariah melalui pembiayaan dan peran bank konvensional melalui kredit terhadap pertumbuhan ekonomi. Pertumbuhan GDP riil diperlakukan sebagai variabel dependen. Alokasi pembiayaan perbankan syariah, kredit perbankan konvensional, indikator kebijakan moneter (SBIS dan nisbah bagi hasil), dan variabel makro ekonomi (inflasi, dan nilai tukar) diperlakukan sebagai variabel independen. Model Estimasi persamaan regresi berganda yang digunakan dalam penelitian ini adalah ;

Model Pertumbuhan Ekonomi :

Grw $_{\text {it }}=\beta_{0}+\beta_{1}$ Int $_{t}+\beta_{2}$ Shr $_{\mathrm{t}}+\beta_{3} \operatorname{Crd}_{\mathrm{t}}+$

$\beta_{4}$ Fin $_{t}+\beta_{5}$ Cpi $_{t}+\beta_{6} \operatorname{Exr}_{t}+\varepsilon \ldots$ (1)

Keterangan :

Grw $=$ pertumbuhan $\mathrm{PDB}$ riil

Cpi $=$ indeks harga konsumen

Int $=$ tingkat bunga Sertifikat bank Indonesia

$\mathrm{Shr}=$ tingkat bagi bagi hasil pada PUAS

$\mathrm{Crd}=$ nilai kredit perbankan

Fin $=$ nilai pembiayaan pada bank syariah

Exr $=$ nilai tukar (kurs) mata uang lokal terhadap dolar USA

Terhadap model penelitian dilakukan berbagai proses uji sebagai berikut ; 1) Uji Hipotesis 2) Uji Kesesuaian Model 3) Uji Signifikansi Parameter 4) Uji Ekonometrik (Uji Normalitas, Uji Otokorelasi, Uji Multikolinearitas dan Uji Heterosedastisitas) .

\section{Hasil dan Pembahasan}

Perkembangan Kredit Bank Konvesional dan Pembiayaan Bank Syariah di Indonesia dalam periode $1992-2018$ tumbuh rata-rata sebesar $16.77 \%$ dan $50.91 \%$ per tahun. Walaupun mengalami pertumbuhan yang tinggi per tahun nya, namun nilai pembiayaan perbankan syariah masih rendah dibanding kredit yang disalurkan oleh indusri perbankan. Tahun 2018 pangsa pasar pembiayaan bank syariah hanya sebesar 5,64\% dari seluruh kredit dan pembiayaan industri perbankan di Indonesia. Perkembangan kondisi pertumbuhan pembiayaan bank syariah dan kredit bank konvensional disajikan dalam gambar 2 berikut ini.

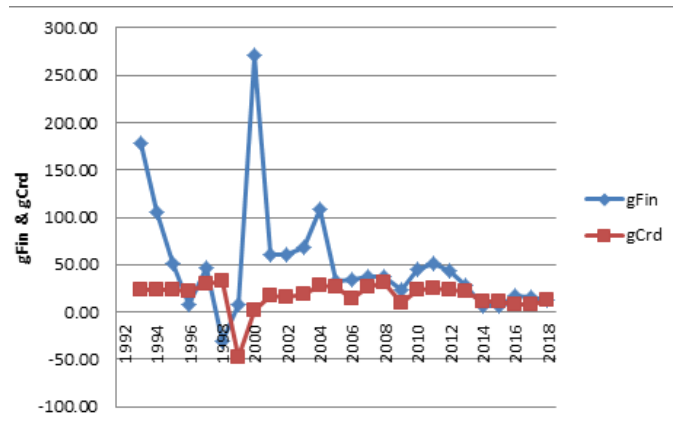

Gambar 2 ; Pertumbuhan Pembiayaan dan Kredit Perbankan di Indonesia periode 1992-2018 (dalam \%)
Proses estimasi model penelitian didasarkan pada sistem persamaan regresi berganda yang dibangun dengan mengacu pada hasil pengujian awal model agar penggunaan metode estimasi dapat dipilih dengan tepat. Estimasi terhadap semua model dilakukan dengan metode Ordinary Least Square (OLS). Hasil estimasi memperlihatkan model nilai tukar memiliki koefisien determinan (Adjusted R2) sebesar 0.994084.

Berdasarkan hasil pengolahan data, model dianggap mampu menjelaskan semua perubahan variabel independen terhadap perubahan variabel dependen. Secara statistik, berdasarkan hasil uji $\mathrm{F}$ model memiliki nilai $F$ statistik tinggi sebesar 729.1247 yang menunjukan bahwa semua nilai variabel independen secara bersama-sama signifikan mempengaruhi variabel dependen. Berdasarkan hasil uji $\mathrm{t}$ semua variabel independen yang digunakan memiliki pengaruh yang signifikan terhadap variabel dependen dan memiliki tanda sesuai dengan hipotesis yang ditentukan. Uji $\mathrm{F}$ dan uji t dilakukan pada taraf keyakinan $95 \%$ dan $99 \%$.

Secara umum dapat diungkapkan bahwa variabel kredit bank konvensional, pembiayaan bank syariah, suku bunga, nisbah bagi hasil, inflasi dan kurs rupiah terhadap US\$ berpengaruh signifikan terhadap pertumbuhan ekonomi di Indonesia. Arah nilai koefisien sesuai dengan perkiraan nilai hipotesis. Hasil estimasi yang menunjukan besar pengaruh dan arah hubungan variabel independen dengan variabel dependen disajikan dalam tabel 1 berikut ini.

TABEL 1

Hasil Estimasi Model Pertumbuhan

\begin{tabular}{|c|c|c|c|c|}
\hline \multicolumn{5}{|c|}{$\begin{array}{l}\text { Dependent Variable: GRW } \\
\text { Method: Least Squares } \\
\text { Sample: } 19922018\end{array}$} \\
\hline Variable & Coefficient & Std. Error & t-Stat & Prob. \\
\hline $\mathrm{C}$ & 9.126213 & 0.794381 & 11.48846 & 0.0000 \\
\hline CRD & 0.322270 & 0.006034 & 53.41310 & 0.0000 \\
\hline FIN & 0.125712 & 0.007637 & 16.46117 & 0.0000 \\
\hline INT & -0.019021 & 0.007854 & -2.421942 & 0.0230 \\
\hline SHR & -0.016457 & 0.007688 & -2.140714 & 0.0422 \\
\hline IHK & 0.916177 & 0.105038 & 8.722356 & 0.0000 \\
\hline EXR & 2.177605 & 0.105836 & 20.57523 & 0.0000 \\
\hline R-squared & 0.995449 & \multirow{3}{*}{\multicolumn{2}{|c|}{$\begin{array}{l}\text { Durbin-Watson stat } \\
\text { Prob(F-statistic) }\end{array}$}} & 0.863879 \\
\hline Adj. R-squared & 0.994084 & & & 0.000000 \\
\hline F-statistic & 729.1247 & & & \\
\hline
\end{tabular}

Dari hubungan antar variabel dependen dengan variabel independen terungkap bahwa peningkatan kredit bank konvensional dan pembiayaan pada perbankan syariah, penurunan tingkat bunga kredit dan bagi hasil perbankan syariah, perkembangan inflasi di dalam negeri serta depresiasi rupiah terhadap US\$ mengakibatkan terjadinya pertumbuhan ekonomi di Indonesia. Semakin meningkat fungsi intermediasi bank dari sisi pengalokasian dana (kredit dan pembiayaan) memberikan kontribusi positif terhadap

56 | Jurnal Akuntansi, Ekonomi dan Manajemen Bisnis | Vol. 8 No.1, July 2020, 52-60 | E-ISSN: 2548-9836 
pertumbuhan ekonomi.

Kontribusi peran perbankan diperkuat oleh dampak negatif dari suku bunga dan nisbah bagi hasil terhadap pertumbuhan ekonomi. Penurunan suku bunga dan nisbah bagi hasil berpengaruh pada peningkatan pertumbuhan ekonomi. Indikator perkembangan harga di dalam negeri (inflasi) dan luar negeri (kurs) juga merupakan bagian yang berpengaruh terhadap pertumbuhan ekonomi. Inflasi dan depresiasi rupiah mengakibatkan terjadinya pertubuhan ekonomi. Penjelasan pengaruh variabel independen kredit bank, pembiayaan bank syariah, suku bunga kredit, nisbah bagi hasil bank syariah, perkembangan inflasi dan depresiasi rupiah terhadap pertumbuhan ekonomi di Indonesia adalah sebagai berikut.

Kredit (bank konvensional) dan pembiayaan (bank syariah) merupakan satu kegiatan utama yang dilakukan industri perbankan. Nilai kredit dan pembiayaan menggambarkan kemampuan bank menyaluran dana ke masyarakat. Peningkatan kredit dan pembiayaan memperkuat fungsi intermediasi lembaga keuangan bank. Jumlah kredit dan pembiayaan menggabarkan potensi dana yang dapat mendorong aktivitas dan pertumbuhan ekonomi di masyarakat.

Hasil penelitian ini mengungkapkan bahwa kredit bank konvensional dan pembiayaan bank syariah berpengaruh signifikan terhadap perumbuhan ekonomi di dalam negeri. Peningkatan kredit dan pembiayaan berpengaruh positif terhadap pertumbuhan ekonomi. Setiap peningkatan $1 \%$ kredit bank konvensional mengakibatkan peningkatan pertumbuhan ekonomi sebesar $0,322 \%$. Setiap peningkatan $1 \%$ pembiayaan bank syariah mengakibatkan peningkatan pertumbuhan ekonomi sebesar $0,126 \%$. Nilai koefisien menunjukan perubahan tidak terlalu besar, bersifat inelastis, namun pengaruhnya signifikan. Setiap peningkatan nilai kredit dan pembiayaan pada industri perbankan di dalam negeri berpotensi mengakibatkan terjadinya pertumbuhan ekonomi.

Hasil penelitian ini sesuai dengan kajian dari Zirek, D., et all (2016), Lehnert \& Kchouri (2019) dan Lebdaoui, \& Wild, J.(2016). Terdapat hubungan signifikan dan sejalan antara lembaga keuangan syariah dan pertumbuhan ekonomi. Peningkatan dana pihak ketiga, aktiva dan pembiayaan bank syariah mendorong terjadinya pertumbuhan ekonomi. Meskipun ukuran bank syariah relatif masih kecil dibandingkan dengan total sektor keuangan yang ada, tetapi perbankan syariah memberikan sumbangan positif terhadap perkembangan perekonomian. Keradaan perbankan syariah terbukti memberikan dampak pada perkembangan perekonomian untuk jangka panjang.

Pengaruh kredit bank konvesional terhadap pertumbuhan ekonomi lebih besar dibandingkan pengaruh pembiayaan bank syariah terhadap pertumbuhan ekonomi. Kredit bank konvensional relatif lebih elastis mendorong pertumbuhan ekonomi dibandingkan dengan bank syariah. Hasil penelitian ini berbeda dengan kajian dari Hasan dan Dridi (2010), yang mengungkapkan bahwa pertumbuhan pembiayaan perbankan syariah memberikan sumbangan pada pertumbuhan ekonomi lebih baik daripada bank konvensional. Hasil kajian dari Hachicha, N., \& Ben Amar, A. (2015) mengungkapkan bahwa dalam jangka panjang, pertumbuhan ekonomi tidak sensitif terhadap pembiayaan dari bank Islam.

Peningkatan kredit bank konvensional dipengaruhi oleh tingkat suku kredit yang berlaku dan berdampak terhadap pertumbuhan ekonomi. Hasil uji menunjukan bahwa suku bunga signifikan berpengaruh negatif terhadap kredit dan pertumbuhan ekonomi. Setiap penurunan suku bunga berdampak terhadap penurunan jumlah kredit dan pertumbuhan ekonomi. Peningkatan pembiayaan bank syariah dipengaruhi oleh nisbah bagi hasil yang berlaku dan berdampak terhadap pertumbuhan ekonomi. Hasil uji menunjukan bahwa nisbah bagi hasil signifikan berpengaruh negatif terhadap pembiayaan dan pertumbuhan ekonomi. Setiap penurunan nisbah bagi berdampak terhadap penurunan jumlah kredit dan pertumbuhan ekonomi. Hasil kajian ini relevan dengan kajian dari Chapra, (2007), yang mengungkapan bahwa larangan sistem bunga dalam akan memperkecil unsur tidak produktif, Sistem bunga menghasilkan inefisiensi alokasi sumber daya dan memperburuk kesejahteraan masyarakat.

Nilai koefisien suku bunga dan nisbah bagi hasil menunjukan nilai perubahan tidak terlalu besar, bersifat inelastis, namun pengaruhnya signifikan. Setiap penurunan suku bunga dan nisbah bagi hasil berpotensi mengakibatkan mendorong pertumbuhan ekonomi. Pengaruh suku bunga bank konvesional terhadap pertumbuhan ekonomi lebih besar dibandingkan pengaruh nisbah bagi hasil bank syariah terhadap pertumbuhan ekonomi. Suku bunga kredit bank konvensional relatif lebih elastis mendorong pertumbuhan ekonomi dibandingkan dengan nisbah bagi hasil bank syariah.

Suku bunga dan nisbah bagi hasil sangat dipengaruhi oleh instrumen kebijakan moneter di Indonesia. Hasil penelitian ini relevan dengan kajian dari Elhiraika (2004) yang mengungkapkan bahwa pelaksanaan kebijakan moneter dalam jangka pendek menghasilkan dampak yang sama bagi bank perbankan konvensional dan perbankan syariah. Perbedaan dampak kebijakan moneter bagi perbankan konvensional dan perbankan syariah akan diperoleh dalam jangka panjang. Dalam jangka panjang keunggulan sistem perbankan syariah tergantung dari lingkungan makro ekonomi yang dihadirkan oleh pemerintah.

Arah hubungan dan nilai pengaruh antar variabel penelitian disajikan dalam gambar 3 berikut ini. 


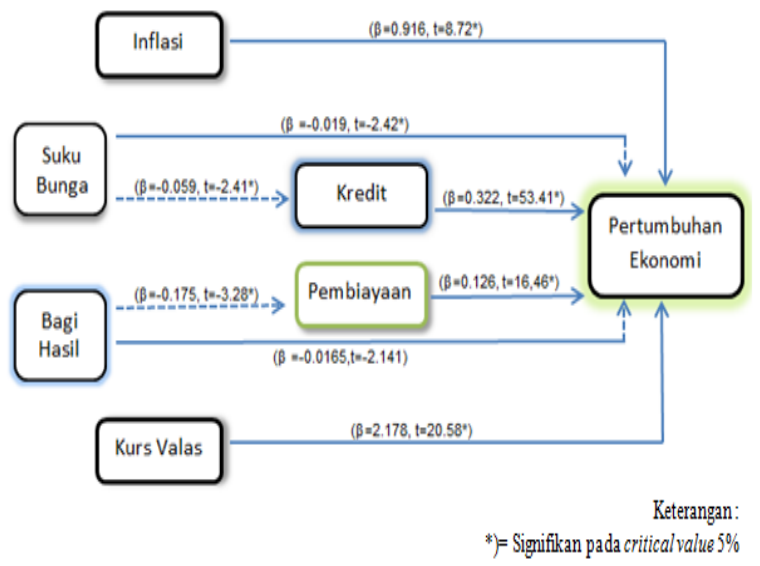

Gambar 3 ; Hubungan dan Nilai Pengaruh antar Variabel Penelitian

Inflasi merupakan variabel pembanding dan nilai kurs rupiah terhadap US\$ merupakan variabel eksternal yang dianggap mempengaruhi pertumbuhan ekonomi. Hasil penelitian ini mengungkapkan bahwa inflasi dan nilai tukar (kurs) mata uang asing (US\$) signifikan dan positif mempengaruhi pertumbuhan ekonomi. Kenaikan harga di dalam negeri (inflasi) dan depresiasi rupiah terhadap US\$ memberikan pengaruh terhadap pertumbuhan ekonomi di Indonesia. Nilai koefisien besarnya pengaruh inflasi terhadap pertumbuhan ekonomi sebesar 0,916. Nilai pengaruhnya cukup besar walau dalam katagori in elastis. Nilai koefisien besarnya pengaruh nilai tukar (kurs) rupiah terhadap pertumbuhan ekonomi sebesar 2,178. Nilai pengaruhnya cukup besar dan bersifat elastis. Setiap kenaikan kurs (depresiasi rupiah) akan mendorong meningkatnya aktivitas ekonomi.

Dalam jangka pendek, setiap kenaikan harga akan mendorong meningkatnya aktivitas ekonomi pelaku usaha dan pertumbuhan ekonomi. Depresiasi rupiah terhadap US\$ akan mengakibatkan terjadi perubahan relatif harga barang ekspor dan barang impor. Barang ekspor menjadi lebih murah (relatif) dan barang impor menjadi lebih mahal (relatif), sehingga akan memperbaiki posisi neraca perdagangan luar negari. Surplus neraca perdagangan akan meningkatan nilai tambah ekonomi di dalam negeri dan mendorong pertumbuhan ekonomi.

Hasil penelitian ini berbeda dengan hasil penelitian dari Craig \& Rochteau (2006). Inflasi memiliki dampak negatif terhadap keseimbangan perekonomian dan inflasi mempengaruhi keputusan pelaku bisnis untuk berpatisipasi di pasar dan karena itu mempengaruhi jumlah perdagangan. Sesuai dengan hasil kajian dari Palley (2007), penelitian ini mengungkap fakta bahwa pengendalian inflasi merupakan proses penting dalam pertumbuhan ekonomi. Target inflasi yang rendah sebagai implementasi dari kebijakan moneter berdampak buruk terhadap pertumbuhan ekonomi.

\section{Simpulan dan Saran}

Hasil penelitian menunjukan bahwa kredit bank konvensional dan pembiayaan bank syariah berpengaruh signifikan terhadap perumbuhan ekonomi di dalam negeri. Peningkatan kredit dan pembiayaan berpengaruh positif terhadap pertumbuhan ekonomi. Setiap peningkatan kredit bank konvensional mengakibatkan peningkatan pertumbuhan ekonomi. Pengaruh perubahan tidak terlalu besar, bersifat inelastis, namun pengaruhnya signifikan. Setiap peningkatan nilai kredit dan pembiayaan pada industri perbankan di dalam negeri berpotensi mengakibatkan terjadinya pertumbuhan ekonomi. Pengaruh kredit bank konvesional terhadap pertumbuhan ekonomi lebih besar dibandingkan pengaruh pembiayaan bank syariah terhadap pertumbuhan ekonomi. Kredit bank konvensional relatif lebih elastis mendorong pertumbuhan ekonomi dibandingkan dengan bank syariah.

Hasil penelitian menunjukan bahwa suku bunga signifikan berpengaruh negatif terhadap kredit dan pertumbuhan ekonomi. Setiap penurunan suku bunga berdampak terhadap penurunan jumlah kredit dan pertumbuhan ekonomi. Peningkatan pembiayaan bank syariah dipengaruhi oleh nisbah bagi hasil yang berlaku dan berdampak terhadap pertumbuhan ekonomi. Nisbah bagi hasil signifikan berpengaruh negatif terhadap pembiaayaan dan pertumbuhan ekonomi. Setiap penurunan nisbah bagi berdampak terhadap penurunan jumlah kredit dan pertumbuhan ekonomi. Nilai koefisien suku bunga dan nisbah bagi hasil menunjukan nilai perubahan tidak terlalu besar, bersifat inelastis, namun pengaruhnya signifikan. Setiap penurunan suku bunga dan nisbah bagi hasil berpotensi mengakibatkan mendorong pertumbuhan ekonomi. Pengaruh suku bunga bank konvesional terhadap pertumbuhan ekonomi lebih besar dibandingkan pengaruh nisbah bagi hasil bank syariah terhadap pertumbuhan ekonomi. Suku bunga kredit bank konvensional relatif lebih elastis mendorong pertumbuhan ekonomi dibandingkan dengan nisbah bagi hasil bank syariah.

Inflasi merupakan variabel pembanding dan nilai kurs rupiah terhadap US\$ merupakan variabel eksternal yang dianggal mempengaruhi pertumbuhan ekonomi. Hasil penelitian ini mengungkapkan bahwa inflasi dan nilai tukar (kurs) mata uang asing (US\$) signifikan dan positif mempengaruhi pertumbuhan ekonomi. Kenaikan harga di dalam negeri (inflasi) dan depresiasi rupiah terhadap US\$ memberikan pengaruh terhadap pertumbuhan ekonomi di Indonesia. Nilai pengaruh inflasi terhadap pertumbuhan ekonomi cukup besar walau dalam katagori in elastis. Nilai pengaruh kurs rupiah terhadap pertumbuhan ekonomi cukup besar dan bersifat elastis. Setiap kenaikan kurs (depresiasi rupiah) akan mendorong meningkatnya aktivitas ekonomi.

Beberapa saran yang perlu disampaika dalam penelitian ini adalah sebagai berikut. Peningkatan 
peran perbankan terhadap proses pembangunan bisa dilakukan dengan mendorong peningkatan kredit bank konvensional dan pembiayaan bank syariah. Peningkatan kredit dan pembiayaan dilakukan terhadap aktivitas produktif yang bisa meningkatkan tingkat pertumbuhan ekonomi. Perlu juga dilakukan upaya menciptakan kondisi tingkat suku bunga rendah dan nisbah bagi hasil yang kompetitif, sehingga jumlah kredit dan pembiayaan meningkat jumlahnya.

Hasil kajian menunjukan bahwa tingkat inflasi dan kurs rupiah berpengaruh positif untuk pertumbuhan ekonomi. Untuk jangka panjang kondisi tidak dipertahankan akan menjadi beban nasional dan daya saing tidak bisa dipertahankan. Perlu peningkatan upaya peningkatan produktivitas dan nilai tambah ekonomi untuk mendorong pelaku bisnis meningkatkan usahanya. Daya siang internasional untuk produk lokal juga perlu ditingkatkan sehingga memiliki keunggulan yang bersifat fundamental dan jangka panjang.

Nisbah bagi hasil yang rendah menunjukan nilai tambah perekonomian yang dilakukan melalui pembiayaan bank syariah masih rendah. Kondisi bisa berdampak buruk pada pertumbuhan ekonomi jangka panjang. Untuk mendorong perkembangan sektor perbankan syariah secara khusus, acuan nisbah bagi hasil sebaiknya mengacu pada kondisi sektor riil, bukan hanya mengacu pada kondisi sektor keuangan. Kelemahan penelitian ini terletak pada penggunaan data pembiayaan secara rata-rata. Untuk penelitian berikutnya sebaiknya digunakan jenis data pembiayaan berdasarkan jenis akad dan tujuan penggunaan. Kontribusi dan peran dari masing-masing jenis pembiayaan dapat diketahui sehingga kebijakan yang paling tepat dapat dipilih untuk mendorong pertumbuhan ekonomi melalui keberadaan perbankan syariah di Indonesia.

\section{Daftar Pustaka}

A. Abdullah, Burhanuddin (2003), Peran Kebijakan Moneter dan Perbankan Dalam Mengatasi Krisis Ekonomi di Indonesia, Bahan Kuliah Kursus Reguler Angkatan XXXVI Lemhanas Tanggal 13 Juni 2003, Jakarta

B. Ahmad, Zuriyati and Ismail, Abdul Ghafar (2019) Alternative Of Monetary Policy Indicator: Panel Data Analysis From Islamic Banks In Malaysia, Journal Of Islamic Monetary Economics And Finance, Vol. 4, No.2 (2018), Pp. $279-292$ P-ISSN: 2460-6146, E-ISSN: 2460-6618.

C. Alam, Tasneem \& Waheed, Muhammad (2006), The Monetary Transmission Mechanism in Pakistan: A Sectoral Analysis (http://ssrn.com/ abstract=971318) Institute of Development Economics, Islamabad, September 2006

D. Alamsyah, Halim ; Doddy Zulverdi ; Iman Gunadi ; Rendra Z. Idris ; Bambang Pramono
(2005) ; Banking Dis-Intermediation And Its Implication For Monetary Policy: The Case Of Indonesia, Buletin Ekonomi Moneter Dan Perbankan, Maret 2005.

E. Ascarya (2010), Peran Perbankan Syariah dalam Transmisi Kebijakan Moneter Ganda, Istishodia, Jurnal Ekonomi Islam Republika, Kamis, 26 Agust 2010.

F. Ascarya, Heni Hasanah, Noer Azam Achsan (2008), Perilaku Permintaan Uang Dalam Sistem Moneter Ganda Di Indonesia, Buletin Ekonomi Moneter Dan Perbankan, Juli 2008

G. Banjarnahor, Nova Riana (2008), Mekanisme Suku Bunga SBI Sebagai Sasaran Operasional Kebijakan Moneter Dan Variabel Makroekonomi Indonesia: 1990.1 - 2007.4, Buletin Ekonomi Moneter Dan Perbankan, Vol. 11 No. 1 Juli 2008 (Hal 21-52)

H. Barata, Amrin (2019), Strengthening National Economic Growth And Equitable Income Through Sharia Digital Economy In Indonesia, Journal of Islamic Monetary Economics and Finance, Vol. 5, No.1 (2019), pp. 145-168 p-ISSN: 2460-6146, e-ISSN: 2460-6618

I. Beck, Thorsten, Asli Demirgüç-Kunt \& Ouarda Merrouche (2013), Islamic vs. conventional banking : Business model, efficiency and stability, Journal of Banking \& Finance, 37 (2013) 433-447

J. Cambazoğlu, Birgül \& Karaalp, H. Simay (2012), The Effect Of Monetary Policy Shock On Employment And Output ; The Case Of Turkey, International Journal Of Emerging Sciences (Ijes), 2(1), 23-29, March 2012, Issn: 2222-4254.

K. Chapra, Umer (2007), The Case Against Interest: Is It Compelling?. Thunder Bird International Business Review, Vol: 49, No: 161-186, Wiley Periodicals.

L. Craig, Ben \& Rocheteau, Guillaume (2006), Inflation And Welfare ; A Search Approach, Policy Discussion Paper Number 12, January 2006, Federal Reserve Bank Of Cleveland. (State-Dependent Pricing, Inflation, And Welfare In Search Economies, European Economic Review, Volume 52, Issue 3, April 2008, Pages 441-468)

M. Elhiraika, Adam B. (2004), On The Design Adn Effect Of Monetary Policy In An Islamic Framework : The Experience Of Sudan, Islamic Development Bank, Islamic Research And Training Institute, Research Paper No. 64, Jeddah 2004.

N. Fikri, Reza Jamilah (2019), Monetary Transmission Mechanism Under Dual Financial System In Indonesia: Credit-Financing Channel, Journal of Islamic Monetary Economics and Finance, Vol. 4, No.2 (2018), pp. 251 - 278 p-ISSN: 2460-6146, e-ISSN: 2460-6618

O. Hachicha, N., \& Ben Amar, A. (2015). Does

59 | Jurnal Akuntansi, Ekonomi dan Manajemen Bisnis | Vol. 8 No.1, July 2020, 52-60 | E-ISSN: 2548-9836 
Islamic Bank Financing Contribute to Economic Growth? The Malaysian Case. International Journal of Islamic and Middle Eastern Finance and Management, 8(3), 349-368

P. Hadiati, Diah (2010), Analisis Vektor Error Corerection Model (Vecm) Pada Hubungan Penyaluran Kredit Kapitalisasi Pasar Modal Dan Suku Bunga Terhadap Pertumbuhan Ekonomi (Studi Khusus Di Indonesia Periode 1997.1 S/D 2009.6). Market Capitalization; Economic Growth.

Q. Hakim Bm and Md Akther Uddin (2016), Does Islamic bank FInancing lead to economic growth: An empirical analysis for Malaysia, INCEIF, MPRA Paper No. 69075, posted 7 June 2016 14:50 UTC, 4 June 2016, Online at https://mpra.ub.uni-muenchen.de/69075/

R. Hasan, Maher and Jemma Dridi (2010), The Effects of the Global Crisis on Islamic and Conventional Banks: A Comparative Study, International Monetary Fund WP/10/201, 2010

S. Jawad, Ahmad and Christian, Klein (2019), Islamic Banking And Economic Growth: Applying The Conventional Hypothesis, Journal of Islamic Monetary Economics and Finance, Vol. 5, No.1 (2019), pp. 37-62 p-ISSN: 2460-6146, e-ISSN: 2460-6618

T. Julaihah, U. dan Insukindro, (2004), Analisis Dampak Kebijakan Moneter Terhadap Variabel Makroekonomi di Indonesia Tahun 1983.1 2003.2., Buletin Ekonomi Moneter dan Perbankan, September, Vol. 7 (2): 323 - 341.

U. Kaleem, Ahmad (2000), Modeling Monetary Stability under Dual Banking System: The Case of Malaysia. ISLAMIC international journal of FINANCIAL SERVICES, ISSN 097-138X Vol.2, No.1, April - June 2000.

V. Lebdaoui, H. and Wild, J.(2016) "Islamic Banking Presence and Economic Growth in Southeast Asia", International Journal of Islamic and Middle Eastern Finance and Management, 9 (4), 551-569

W. Lehnert, Thorsten and Kchouri, B. (2019) Islamic Finance and Economic Growth: New vidence. (Unpublished) paper presented in The 9th International Conference on Economics, 23 Jan to 25 Jan 2019.

X. Mendoza, Enrique G. And Terrones, Marco E. (2008), An Anatomy Of Credit Booms: Evidence From Macro Aggregates And Micro Data, Nber Working Paper No. 14049, May 2008, Jel No. E32,E44,E51,F3,G21

Y. Ozcelebi, Oguzhan (2011), Do Monetary Policy Stance And Participation Banking Influence The Real Economic Activity, Empirical Evidence From Turkey, International Research Journal Of Finance And Economics Issn 1450-2887 Issue 77.

Z. Palley, Thomas I. (2007), Macroeconomics And
Monetary Policy: Competing Theoretical Frameworks, Economics For Democratic \& Open Societies, Washington Dc, Mail@Thomaspalley.Com , February 2007

AA. Prastowo, Nugroho Joko, \& Depari, Yoni (2008), Dampak Financial Deepening Terhadap Pelaksanaan Kebijakan Moneter Di Indonesia, Working Paper (Wp/21/2008), Laporan Hasil Penelitian Bank Indonesia, Desember 2008.

BB. Rusydiana, Aam Slamet (2009), Mekanisme Transmisi Syariah pada Sistem Moneter Ganda di Indonesia, Buletin Ekonomi Moneter dan Perbankan Bank Indonesia, Volume 11, Nomor 4, April. 2009, hal 345-368.

CC. Rusydiana, Aam Slamet (2016), Analisis Masalah Pengembangan Perbankan Syariah Di Indonesia: Aplikasi Metode Analytic Network Process, Esensi: Jurnal Bisnis dan Manajemen Volume 6 (2), Oktober 2016 P-ISSN: 2087-2038; E-ISSN:2461-1182 Halaman 237 - 246 http://journal. uinjkt.ac.id/index.php/esensi DOI: $10.15408 /$ ess.v6i2.3573 237

DD. Saibu M. O \& Nwosa I (2011) ; Monetary Policy on Sectoral Output Growth in Nigeria (1986-2008), Journal of Economics and Behavioral Studies, Vol. 2, No. 6, pp. 245-254, June 2011

EE. Shah, Rehman \& Abdul, Syed Muhammad (2019), The Credit Supply Channel Of Monetary Policy Transmission Mechanism: An Empirical Investigation Of Islamic Banks In Pakistan Versus Malaysia, Journal Of Islamic Monetary Economics And Finance, Vol. 5, No.1 (2019), Pp. 21-36 P-ISSN: 2460-6146, E-ISSN: 2460-6618

FF. Sukmana, Raditya (2011), Economic sectors sensitivity to Islamic and conventional Monetary Instrument: Case study in Indonesia, 8th International Conference on Islamic Economics and Finance, Doha, Qatar - December 25-27, 2011

GG. Sutikno, (2007) Dampak Kebijakan Moneter TerhadapPerformance Makro Ekonomi Indonesia (Sebelum Dan Pasca Krisis Ekonomi), Publikasi Penelitian Fakultas Ekonomi Universitas Muhammdiyah Malang, 2007

HH. Zirek, D., Celebi, F., \& Hassan, M. K. (2016). The Islamic Banking and Economic Growth Nexus: A Panel VAR Analysis for Organization of Islamic Cooperation (OIC) Countries. Journal of Economic Cooperation \& Development, 37 (1), 69 .

60 | Jurnal Akuntansi, Ekonomi dan Manajemen Bisnis | Vol. 8 No.1, July 2020, 52-60 | E-ISSN: 2548-9836 